\title{
Electrochemical synthesis of ammonia in solid electrolyte cells
}

\author{
Ioannis Garagounis ${ }^{1,2}$, Vasileios Kyriakou ${ }^{1,2}$, Aglaia Skodra ${ }^{2}$, Eirini Vasileiou ${ }^{1,2}$ and Michael Stoukides ${ }^{1,2} *$ \\ ${ }^{1}$ Department of Chemical Engineering, Aristotle University of Thessaloniki, Thessaloniki, Greece \\ ${ }^{2}$ Chemical Processes and Energy Resources Institute, Center for Research and Technology Hellas, Thessaloniki, Greece
}

Edited by:

Shanwen Tao, University of

Strathclyde, UK

Reviewed by:

Sarbjit S. Giddey, CSIRO Energy

Technology, Australia

Rong Lan, University of Strathclyde,

UK

*Correspondence:

Michael Stoukides, Department of

Chemical Engineering, Aristotle

University of Thessaloniki, Building

E13, Laboratory of Electrochemical

Processes, Thessaloniki 54124,

Greece

e-mail: stoukidi@cperi.certh.gr
Developed in the early 1900s, the "Haber-Bosch" synthesis is the dominant $\mathrm{NH}_{3}$ synthesis process. Parallel to catalyst optimization, current research efforts are also focused on the investigation of new methods for ammonia synthesis, including the electrochemical synthesis with the use of solid electrolyte cells. Since the first report on Solid State Ammonia Synthesis (SSAS), more than 30 solid electrolyte materials were tested and at least 15 catalysts were used as working electrodes. Thus far, the highest rate of ammonia formation reported is $1.13 \times 10^{-8} \mathrm{~mol} \mathrm{~s}^{-1} \mathrm{~cm}^{-2}$, obtained at $80^{\circ} \mathrm{C}$ with a Nafion solid electrolyte and a mixed oxide, $\mathrm{SmFe}_{0.7} \mathrm{Cu}_{0.1} \mathrm{Ni}_{0.2} \mathrm{O}_{3}$, cathode. At high temperatures $\left(>500^{\circ} \mathrm{C}\right)$, the maximum rate was $9.5 \times 10^{-9} \mathrm{~mol} \mathrm{~s}^{-1} \mathrm{~cm}^{-2}$ using $\mathrm{Ce}_{0.8} \mathrm{Y}_{0.2} \mathrm{O}_{2-\delta}-\left[\mathrm{Ca}_{3}\left(\mathrm{PO}_{4}\right)_{2}-\mathrm{K}_{3} \mathrm{PO}_{4}\right]$ as electrolyte and $\mathrm{Ag}-\mathrm{Pd}$ as cathode. In this paper, the advantages and the disadvantages of SSAS vs. the conventional process and the requirements that must be met in order to promote the electrochemical process into an industrial level are discussed.

Keywords: ammonia synthesis, solid electrolytes, proton conductors, oxygen conductors, solid state ammonia synthesis

\section{INTRODUCTION}

In September 2013, 100 years were completed since the first industrial reactor for ammonia synthesis was put in operation. Designed by Carl Bosch and still standing in a garden in front of the BASF Ammonia Synthesis Institute, this high-pressure reactor could produce 5 tons of ammonia per day (Liu, 2013). With the fertilizer industry being by far its primary user, currently, the worldwide production of ammonia is over 100 million tons per year (Amar et al., 2011a).

The development of an industrial process for ammonia synthesis from its elements:

$$
\mathrm{N}_{2}+3 \mathrm{H}_{2} \Leftrightarrow 2 \mathrm{NH}_{3}
$$

is considered as the bellwether reaction of heterogeneous catalysis (Boudart, 1994) and has played a central role in the development of the chemical industry during the twentieth century (Topsoe et al., 1994). The Haber-Bosch process, which involves reaction of gaseous nitrogen and hydrogen on an Fe-based catalyst at highpressures (150-300 bar) was developed in the early 1900s after an extensive search for materials with an industrially acceptable catalytic activity (Satterfield, 1980; Topsoe et al., 1994). The nitrogen molecule, $\mathrm{N}_{2}$, is one of the most stable molecules in nature; the triple bond between the two $\mathrm{N}$ atoms has a binding energy of $962 \mathrm{~kJ} / \mathrm{mol}$. Moreover, in addition to the difficulty in dissociating $\mathrm{N}_{2}$, the reaction conversion is limited by thermodynamics. The gas volume decreases with reaction. Therefore, very high-pressures must be used in order to push the equilibrium to the right according to the Le Chatelier principle. In the early stages of the development of the process, very high-pressures (500-1000 bar) were used (Satterfield, 1980). The equilibrium conversion decreases with temperature because the reaction is exothermic $(-46 \mathrm{~kJ} / \mathrm{mol}$ at $298 \mathrm{~K}$ ). Hence, if only thermodynamics is taken into account, it would be preferable to operate at room temperature at which the predicted conversion would be higher than $90 \%$ at atmospheric pressure. The reaction kinetics, however, are unacceptably slow at room temperature. Thus, the trade-off solution was to operate at temperatures near $450^{\circ} \mathrm{C}$ and at pressures between 150 and 300 bars in order to obtain an equilibrium conversion of the order of $10-15 \%$ (Amar et al., 2011a). It is beyond the purpose of this communication to review the research that has been conducted thus far concerning the kinetics and the mechanism of ammonia synthesis. Numerous papers can be found in literature. Fortunately, earlier and recent works have been reviewed in the last three decades (Topsoe et al., 1994; Liu, 2013).

Nature converts molecular $\mathrm{N}_{2}$ into $\mathrm{NH}_{3}$ without the use of high temperatures and pressures (Rod et al., 2000; Schrock, 2006; Skúlason et al., 2012). This natural process utilizes metalloenzymes and has been developed and optimized over a period of a few billion years (Schrock, 2006). The enzymes, called nitrogenases, contain iron and molybdenum and catalyze the reaction of ammonia synthesis from atmospheric nitrogen, protons, and electrons (Schrock, 2006; Skúlason et al., 2012). The high efficiency of this enzyme-catalyzed synthesis has attracted the interest of researchers in imitating nature. In the last two decades, remarkable progress has been achieved in both, understanding the mechanism of the biological process and developing an "artificial" abiological process using transition metal complexes (Yandulov and Schrock, 2003; Studt and Tuczec, 2005; Skúlason et al., 2012).

Since its discovery, the Haber-Bosch process has been substantially improved and optimized. The continuous search for more active catalysts resulted in operation at lower temperatures and 
consequently, at lower pressures. Parallel to catalyst optimization, research efforts also focus on the investigation of new methods for ammonia synthesis, including the electrochemical synthesis in aqueous or solid electrolyte cells (Garagounis et al., 2011). Several studies in which ammonia was electrochemically produced in aqueous media have been reported (Kordali et al., 2000; Köleli and Rőpke, 2006). One problem, however, with aqueous electrolytes is that the operating temperature must be low. At low temperature, the kinetic reaction rates are inevitably slow. The discovery and development of solid state proton $\left(\mathrm{H}^{+}\right)$conductors (Iwahara et al., 1981) offered the opportunity to produce ammonia at elevated temperatures. The first work on Solid State Ammonia Synthesis (SSAS) was reported by Marnellos and Stoukides (1998). Since then, groups worldwide have studied this subject and number of problems that should be solved in order to enable scale-up have been identified. A comprehensive review of the SSAS studies reported until the end of 2010 was published by Amar et al. (2011a). The cell component requirements were discussed with emphasis on the solid electrolyte materials. Recently, Giddey et al. (2013) carefully reviewed the progress on the electrochemical production of ammonia with emphasis on materials of construction, major technical challenges, and status of technology.

The present review focuses primarily on SSAS. The properties and requirements to be met by the working electrode (WE), which also serves as the ammonia synthesis catalyst, are discussed in more detail. The electrochemical results are compared to those obtained by the catalytic process. Finally, the hurdles to be overcome in order to bring SSAS into industrial practice are discussed.

\section{AMMONIA SYNTHESIS IN PROTON $\left(\mathrm{H}^{+}\right)$CONDUCTING CELLS}

Figure 1 shows schematically the principle of SSAS from gaseous $\mathrm{N}_{2}$ and $\mathrm{H}_{2}$ in a proton-conducting solid electrolyte cell. The cell consists of a solid state $\mathrm{H}^{+}$conductor. Two porous metal films are placed on the two sides of the solid electrolyte and serve as electrodes. Gaseous $\eta_{2}$ passes over the anode where it is converted to protons $\left(\mathrm{H}^{+}\right)$according to the reaction:

$$
3 \mathrm{H}_{2} \Leftrightarrow 6 \mathrm{H}^{+}+6 \mathrm{e}^{-} \text {. }
$$

In the form of protons, hydrogen is transported through the electrolyte to the cathode, where the half-cell reaction

$$
\mathrm{N}_{2}+6 \mathrm{H}^{+}+6 \mathrm{e}^{-} \Leftrightarrow 2 \mathrm{NH}_{3}
$$

takes place. Thus, reaction (1) is again the overall reaction with the cathodic electrode serving as catalyst for ammonia synthesis.

The use of proton-conducting solid electrolyte cells to bypass the thermodynamic constraints of reversible hydro- or dehydrogenation reactions was proposed in the mid 1990s (Marnellos et al., 1996, 1997; Panagos et al., 1996). Panagos et al. (1996) developed a model that showed that, if an $\mathrm{H}^{+}$cell is used, the product yield of a hydrogenation reaction can exceed that of the corresponding catalytic reactor by several orders of magnitude. Marnellos et al. used that model to examine the performance of various types of electrochemical reactor design and discussed the parameters that affect the reaction conversion (Marnellos et al., 1996, 1997, 1998, 2000).

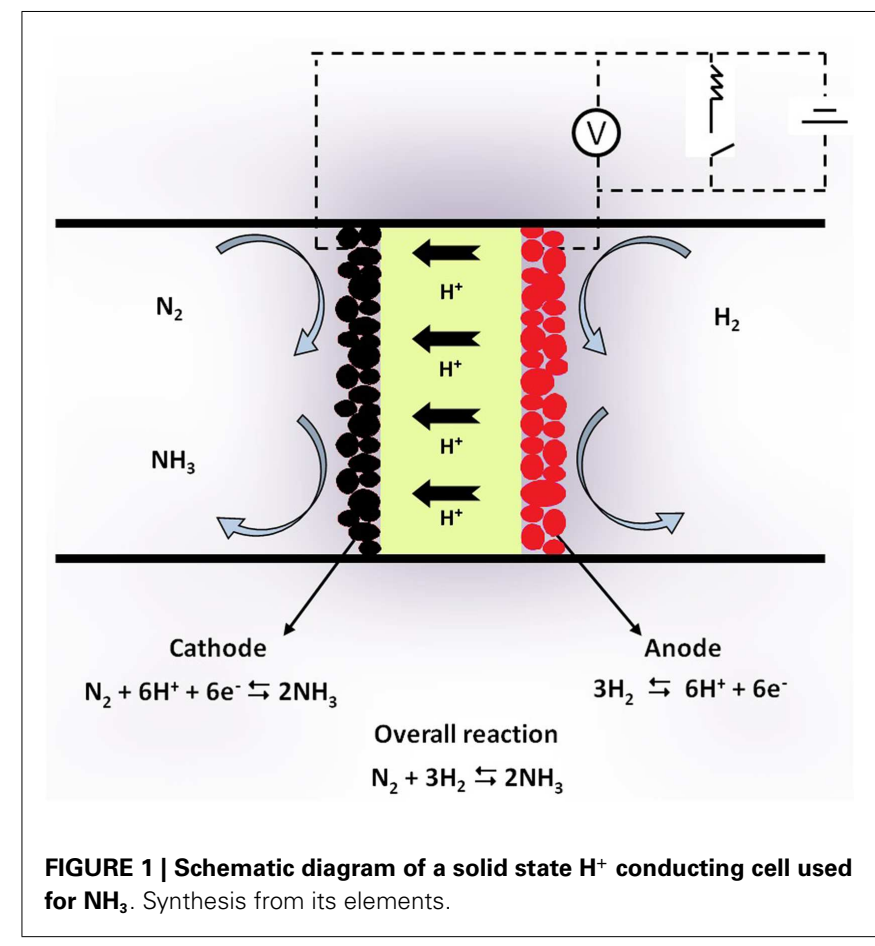

Experimental verification of SSAS was first demonstrated by Marnellos and Stoukides (1998). The solid electrolyte cell used was of the form: $\mathrm{H}_{2} / \mathrm{Pd} / \mathrm{SCY} / \mathrm{Pd} / \mathrm{N}_{2}$. The $\mathrm{H}^{+}$conductor (SCY) was a strontia-ceria-ytterbia perovskite of the form $\mathrm{SrCe}_{0.95} \mathrm{Yb}_{0.05} \mathrm{O}_{3}$. Two porous polycrystalline Pd films were used as electrodes. At $570^{\circ} \mathrm{C}$ and atmospheric pressure, $78 \%$ of the supplied protons were converted into ammonia.

In the past 15 years, a large number of researchers have studied this system. Table 1 contains the SSAS works published until September 2013. The first column on the left-hand side shows the formula (and its abbreviated name in parentheses) of the solid electrolyte that was used. Similarly, the second column shows the WE used. The third column contains the reference of each work. In all the studies listed in Table 1, reactions (2) and (3) occurred at the anode and cathode, respectively. Hence, ammonia was formed at the cathode (WE).

\section{PROGRESS WITH H+ CONDUCTING CELLS}

In the industrial production of ammonia, a significant fraction of the cost lies in the preparation and purification of the feed gas (Satterfield, 1980; Amar et al., 2011a). The catalyst is easily poisoned by oxygen and sulfur compounds. Hydrogen is usually produced from steam reforming of natural gas, which contains such compounds. Therefore, alternative hydrogen sources, which could eliminate natural gas, would reduce the overall cost of ammonia and the carbon footprint (Amar et al., 2011a; Giddey et al., 2013).

Using Nafion as a proton conductor and an $\mathrm{Ru} / \mathrm{C}$ cathode, Kordali et al. (2000) produced $\mathrm{NH}_{3}$ from $\mathrm{H}_{2} \mathrm{O}$ and $\mathrm{N}_{2}$ at $90^{\circ} \mathrm{C}$. The same approach was successfully tested at elevated temperatures using a perovskite type of proton conductor; the reactants were steam and gaseous nitrogen (Skodra and Stoukides, 2009). Wang et al. (2007) synthesized ammonia using natural gases $\left(\mathrm{CH}_{4}\right.$ 
Table 1 |The proton-conducting electrolytes and electrodes used by various investigators in solid state ammonia synthesis cells.

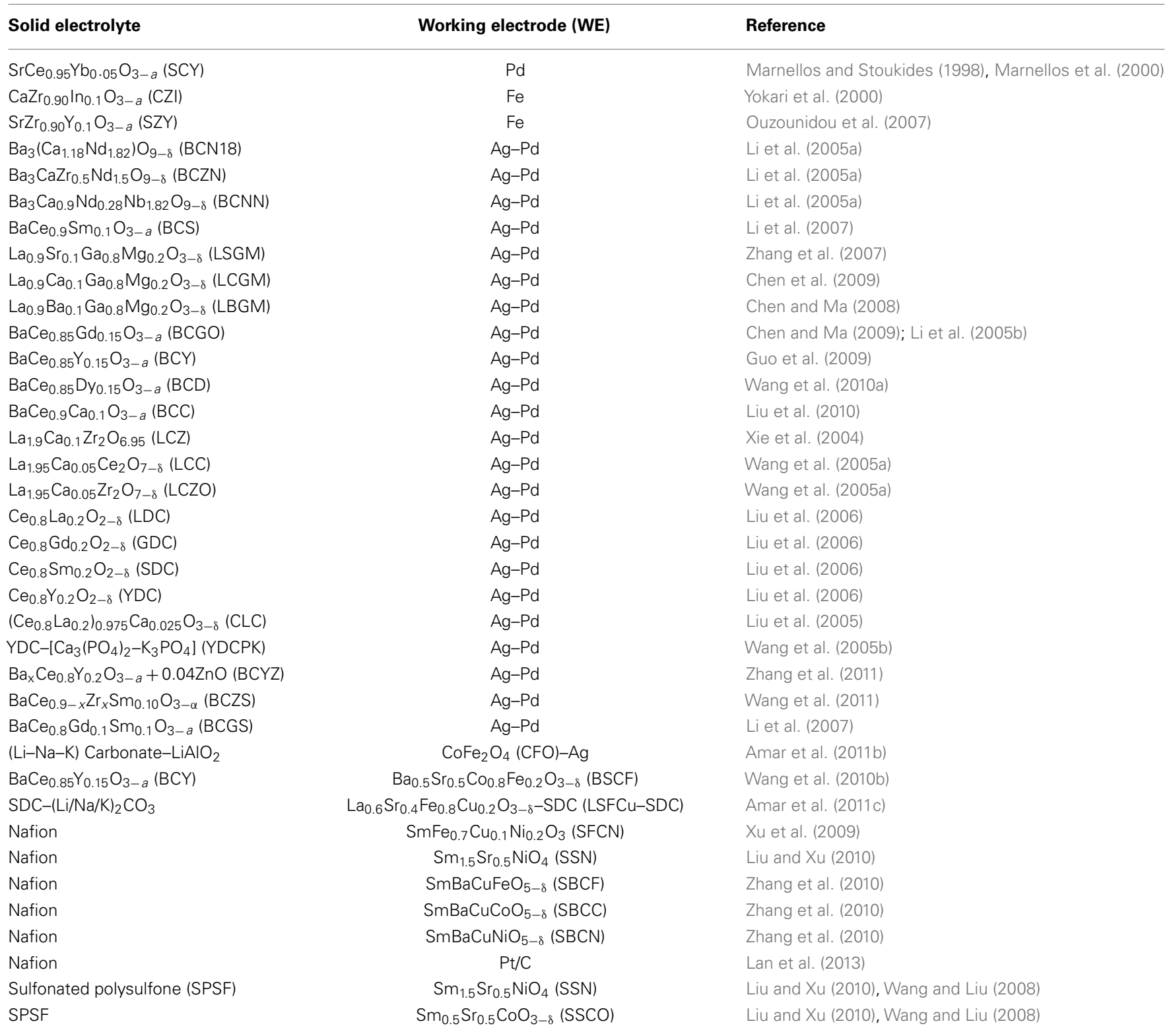

or $\mathrm{C}_{2} \mathrm{H}_{6}$ ) rather than $\mathrm{H}_{2}$ as a hydrogen source. Recently, Lan et al. reported $\mathrm{NH}_{3}$ synthesis from air and $\mathrm{H}_{2} \mathrm{O}$ at room temperature (Lan and Tao, 2013; Lan et al., 2013).

Ammonia is a pure hydrogen source for fuel cell applications. To this end, solid state $\mathrm{H}^{+}$conducting cells were used to study the decomposition of $\mathrm{NH}_{3}$ on $\mathrm{Ru}$ (Skodra et al., 2006), Fe (Pitselis et al., 1997), and Ag (Zisekas et al., 2008) electrodes. Moreover, the idea to use $\mathrm{NH}_{3}$ as a fuel was tested in both $\mathrm{H}^{+}$and $\mathrm{O}^{2-}$ solid electrolyte cells with promising results (McFarlan et al., 2004; Pelletier et al., 2005).

The above progress with solid state proton conductors is summarized in Table 2. The solid electrolyte and the WE used in each study are shown in the first and second columns, respectively. The third column shows the reactants and products and the last column contains the reference(s) of each work.

\section{ELECTROCHEMICAL SYNTHESIS OF AMMONIA IN OTHER (NOT $\mathrm{H}^{+}$) ELECTROLYTE CELLS}

As already mentioned, plants can convert molecular $\mathrm{N}_{2}$ into $\mathrm{NH}_{3}$ with a process that involves metalloenzymes, protons, and electrons. Hence, this natural process should also be considered as an "electrochemical" synthesis. Similarly, laboratory studies of $\mathrm{NH}_{3}$ synthesis using transition metal complexes (Yandulov and Schrock, 2003; Studt and Tuczec, 2005; Skúlason et al., 2012) or organic solvent based electrolytes (Tsuneto et al., 1994) should be considered as electrochemical processes as well. All these works, however, are not discussed here. The present review is limited to "classical" electrochemical processes, in which an electrochemical cell is used and $\mathrm{NH}_{3}$ is formed either from $\mathrm{H}_{2}$ and $\mathrm{N}_{2}$ or from $\mathrm{H}_{2} \mathrm{O}$ and $\mathrm{N}_{2}$.

The use of $\eta_{2} \mathrm{O}$, instead of $\eta_{2}$, inspired an alternative approach to $\mathrm{NH}_{3}$ synthesis, which is based on the use of oxygen ion $\left(\mathrm{O}^{2-}\right)$ 
Table 2 |The reactants and products formed in electrochemical ammonia synthesis and ammonia utilization cells using alternative hydrogen sources.

\begin{tabular}{lcll}
\hline Solid electrolyte & Working electrode & Reactants and products & Reference \\
\hline Nafion & $\mathrm{Ru} / \mathrm{C}$ & $\mathrm{N}_{2}, \mathrm{H}_{2} \mathrm{O} \rightarrow \mathrm{NH}_{3}, \mathrm{O}_{2}$ & Kordali et al. (2000) \\
SZY & $\mathrm{Ru}$ & $\mathrm{N}_{2}, \mathrm{H} \mathrm{O} \rightarrow \mathrm{NH}_{3}, \mathrm{O}_{2}$ & Skodra and Stoukides (2009) \\
Mixed $\mathrm{NH}_{4}+/ \mathrm{H}^{+}$Nafion & $\mathrm{Pt}$ & $\mathrm{N}_{2}$ (Air), $\mathrm{H}_{2} \mathrm{O} \rightarrow \mathrm{NH}_{3}, \mathrm{O}_{2}$ & Lan et al. (2013) \\
Mixed H+/Li+/ $\mathrm{NH}_{4}+$ & $\mathrm{Nt} / \mathrm{C}$ & $\mathrm{N}_{2}$ (Air), $\mathrm{H}_{2} \mathrm{O} \rightarrow \mathrm{NH}_{3}, \mathrm{O}_{2}$ & Lan and Tao (2013) \\
YDCPK & $\mathrm{Ag}-\mathrm{Pd}$ & $\mathrm{NH}_{3} \rightarrow \mathrm{N}_{2}, \mathrm{H}_{2}$ & Wang et al. (2007) \\
$\mathrm{SZY}$ & $\mathrm{Ru}$ & $\mathrm{NH}_{3} \rightarrow \mathrm{N}_{2}, \mathrm{H}_{2}$ & Skodra et al. (2006) \\
$\mathrm{CZI}$ & $\mathrm{Fe}$ & $\mathrm{NH}_{3} \rightarrow \mathrm{N}_{2}, \mathrm{H}_{2}$ & Pitselis et al. (1997) \\
SCY & $\mathrm{Ag}$ & $\mathrm{NH}_{3}, \mathrm{O}_{2} \rightarrow \mathrm{N}_{2}, \mathrm{H}_{2} \mathrm{O}$ & Zisekas et al. (2008) \\
BCG, BCGP & $\mathrm{Pt}$ & Pelletier et al. (2005), McFarlan et al. (2004)
\end{tabular}

conductors. In this case, the solid electrolyte cell is schematically shown in Figure 2. Steam and nitrogen are introduced together at the cathode, where the reactions that take place can be summarized as:

$$
3 \mathrm{H}_{2} \mathrm{O}+6 \mathrm{e}^{-} \Leftrightarrow 3 \mathrm{O}^{2-}+3 \mathrm{H}_{2},
$$

and

$$
3 \mathrm{H}_{2}+\mathrm{N}_{2} \Leftrightarrow 2 \mathrm{NH}_{3} .
$$

At the anode, $\mathrm{O}^{2-}$ is converted to $\mathrm{O}_{2}$ :

$$
3 \mathrm{O}^{2-} \Leftrightarrow \frac{3}{2} \mathrm{O}_{2}+6 \mathrm{e}^{-}
$$

and thus, the overall reaction is:

$$
3 \mathrm{H}_{2} \mathrm{O}+\mathrm{N}_{2} \Leftrightarrow 2 \mathrm{NH}_{3}+\frac{3}{2} \mathrm{O}_{2} .
$$

The feasibility of a process in which $\mathrm{NH}_{3}$ is electrochemically produced from $\mathrm{H}_{2} \mathrm{O}$ (steam) and $\mathrm{N}_{2}$ in $\mathrm{O}^{2-}$ conducting solid electrolyte cells has been successfully demonstrated (Skodra and Stoukides, 2009). The rate of $\mathrm{NH}_{3}$ formation was negligibly small at $500^{\circ} \mathrm{C}$, but at higher temperatures, an increase by up to two orders of magnitude was observed.

Although the reaction rates observed were lower than those obtained in $\mathrm{H}^{+}$cells, the use of $\mathrm{O}^{2-}$ conductors offers an additional advantage: pure $\mathrm{O}_{2}$, already separated from the reacting mixture, is the by-product.

In the last decade, a number of researchers studied the electrochemical synthesis of $\mathrm{NH}_{3}$ in molten salt systems (Vayenas et al., 2001; Murakami et al., 2003, 2005; Denvir et al., 2004; Murphy et al., 2008; Serizawa et al., 2012). In such a molten salt system, the reactions on the two electrodes can be written as:

$$
\begin{aligned}
& \text { Cathode: } \frac{1}{2} \mathrm{~N}_{2}+3 \mathrm{e}^{-} \Leftrightarrow \mathrm{N}^{3-}, \\
& \text { Anode: } \mathrm{N}^{3-}+\frac{3}{2} \mathrm{H}_{2} \Leftrightarrow \mathrm{NH}_{3}+3 \mathrm{e}^{-},
\end{aligned}
$$

so that Eq. 1 is the overall reaction. Recently, $\mathrm{NH}_{3}$ synthesis was studied by Serizawa et al. (2012) in a molten $\mathrm{LiCl}-\mathrm{KClCsCl}$ system at temperatures between 360 and $390^{\circ} \mathrm{C}$. It was found that a

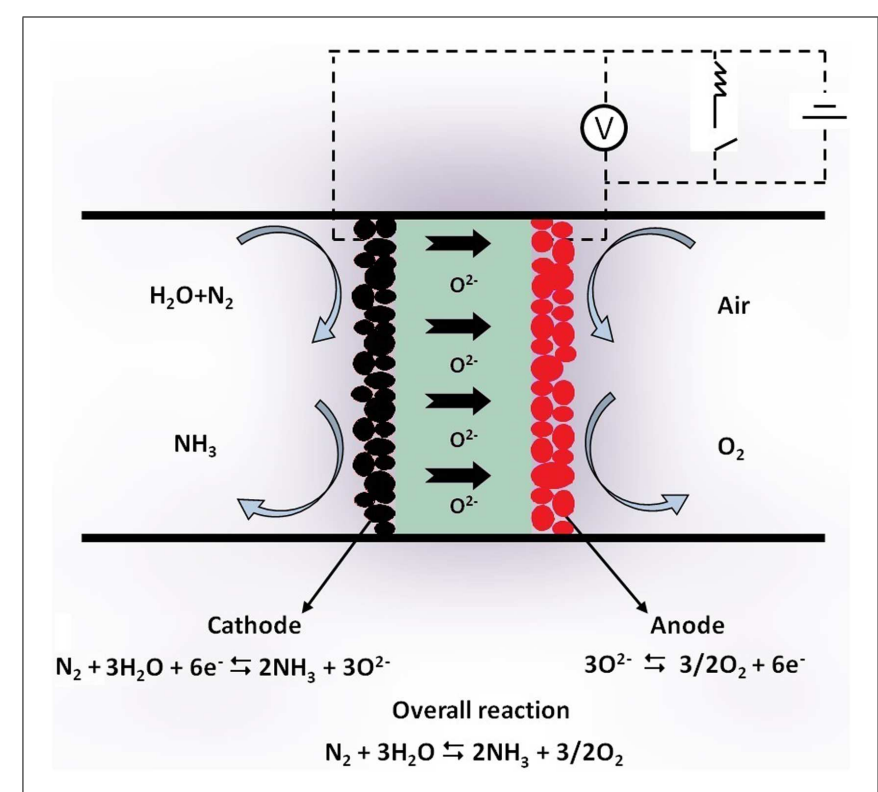

FIGURE 2 | Schematic diagram of $\mathrm{NH}_{3}$ synthesis in an $\mathrm{O}^{2-}$ cell.

portion of $\mathrm{NH}_{3}$ was chemically dissolved in the melt in the form of imide $\left(\mathrm{NH}^{2-}\right)$ and amide $\left(\mathrm{NH}_{2}^{-}\right)$anions resulting in a decrease of the $\mathrm{NH}_{3}$ yield. Despite side reactions, conversions of $\mathrm{Li}_{3} \mathrm{~N}$ into $\mathrm{NH}_{3}$ as high as $70 \%$ were obtained.

\section{ELECTROCHEMICAL PROMOTION DURING SSAS}

Solid electrolytes can be used for the electrochemical promotion of the rates of heterogeneous catalytic reactions. This can be achieved if the catalyst to be promoted is the WE of the solid electrolyte cell. For the reaction of ammonia synthesis, the phenomenon of electrochemical promotion can be studied in the $\mathrm{H}^{+}$cell of Figure 1 . If the circuit is open (zero current) and a gaseous mixture of $\mathrm{N}_{2}$ and $\mathrm{H}_{2}$ is introduced over the cathode, the cell will operate as a catalytic reactor. Thus, ammonia will be formed under open circuit, at a rate denoted as $r_{\mathrm{o}}$ (and expressed in moles of hydrogen reacting per second). When the circuit is closed and a current $I$ is imposed, the cell will additionally function as an electrochemical proton "pump." The reaction rate will increase from $r_{\mathrm{o}}$ to $r$. The effect of electrochemical "pumping" can be quantified by the use 
of two dimensionless parameters (Vayenas et al., 2001; Vayenas and Koutsodontis, 2008):

$$
\Lambda=\frac{\Delta r}{I / 3 F}
$$

and

$$
\rho=\frac{r}{r_{\mathrm{o}}}
$$

with $\Lambda$ being the Faradaic efficiency, $\rho$ the rate enhancement ratio, and $\Delta r$ the difference between closed and open circuit rate: $\Delta r=r-r_{o}$.

If $\Lambda=1$, the effect is Faradaic, i.e., the increase in reaction rate equals the rate of $\mathrm{H}^{+}$transport through the electrolyte. If $\Lambda>1$, the effect is non-Faradaic. In the past 30 years, the phenomenon of Non-Faradaic Electrochemical Modification of Catalytic Activity (NEMCA), also called Electrochemical Promotion of Catalysis (EPOC), has been observed in many catalytic reaction systems (Vayenas et al., 2001; Vayenas and Koutsodontis, 2008; Vayenas, 2011) including oxidations, reductions, hydrogenations, decompositions, and isomerizations. Values of $\Lambda$ and $\rho$ as high as $3 \times 10^{5}$ and 1400, respectively, have been reported (Vayenas and Koutsodontis, 2008; Vayenas, 2011). Most of the experimental and theoretical NEMCA studies conclude that this phenomenon is due to the introduction of charged species from the solid electrolyte to the catalyst/gas interface, followed by the formation of a neutral double layer. This double layer alters the work function of the catalyst surface resulting in a reversible alteration of the catalytic reaction rate (Vayenas et al., 2001; Vayenas and Koutsodontis, 2008; Vayenas, 2011). NEMCA is a powerful tool in heterogeneous catalysis because (a) the surface modification can be monitored electrochemically and in a reversible manner and (b) the increase in the reaction rate can exceed the rate of ion supply by several orders of magnitude (Garagounis et al., 2011; Vayenas, 2011).

The phenomenon of Electrochemical Promotion has been investigated in only a few SSAS works. Marnellos et al. studied the reaction on a Pd electrode and observed very low $\Lambda$ and $\rho$ values, i.e., $\Lambda<2.0$ and $\rho<1.5$ (Marnellos and Stoukides, 1998; Marnellos et al., 2000). Yokari et al. (2000) used an industrial Fe catalyst and measured $\rho$ values as high as 13 when protons were "pumped" toward the catalyst surface. On the contrary, upon "pumping" $\mathrm{H}^{+}$ away from the catalyst, it was possible to obtain a complete loss of the catalytic activity. Pitselis et al. studied the reverse reaction (ammonia decomposition) on an Fe catalyst. A significant decrease in the reaction rate was observed upon pumping $\mathrm{H}^{+}$to the catalyst surface. Values of $\Lambda$ and $\rho$ up to 150 and 3.5, respectively, were observed (Pitselis et al., 1997). Skodra and Stoukides, who studied the decomposition of $\mathrm{NH}_{3}$ using $\mathrm{Ru}$ as WE, observed $\Lambda$ 's as high as 4.0 when pumping $\mathrm{H}^{+}$away from the catalyst surface (Skodra et al., 2006). Zisekas et al. studied the reaction on Ag electrodes. Although the $\Lambda$ 's remained near unity in all experiments, $\rho$ values as high as 57 were achieved (Zisekas et al., 2008).

A general observation is that, as opposed to catalytic oxidations, hydrogenation reactions, such as ammonia synthesis, exhibit weak NEMCA characteristics (Vayenas et al., 2001; Vayenas and Koutsodontis, 2008; Vayenas, 2011; Garagounis et al., 2013). Recently,
Garagounis et al. (2013) presented a thermodynamic analysis of NEMCA for reactions with limited equilibrium conversion. The reaction of ammonia synthesis was used as a model system. The model predictions, which were in agreement with the existing experimental results, indicated that for ammonia synthesis at temperatures between 500 and $600^{\circ} \mathrm{C}, \Lambda$ could not exceed the value of 10. The physical explanation of the model predictions is that, as opposed to reactions with highly negative free energy change, the effect of $\mathrm{H}^{+}$pumping on equilibrium limited reactions is both, electrochemical and catalytic. The pumped protons not only modify the catalytic properties of the $\mathrm{WE}$, but also serve as the carriers of the electrical power required for ammonia synthesis (Garagounis et al., 2013) thus reducing their promotional effect.

\section{COMPARING CATALYTIC AND ELECTROCATALYTIC SYNTHESIS}

The catalytic reaction of ammonia synthesis from its elements has been studied extensively in the past 100 years. Today, the mechanism of the catalytic synthesis is well understood (Skúlason et al., 2012) and consequently, a considerable improvement and optimization of the Haber-Bosch process has been achieved. On the other hand, the electrocatalytic synthesis has been investigated in the last 15 years and quite a few questions need to be answered.

A comparison of the two processes could start by listing the factors that affect the rate of ammonia formation in each case. In addition to the reactant feed composition, the inlet flow rate and the catalyst used, the catalytic rate depends on the pressure and the temperature of operation. Under the conditions employed in the industrial practice, the reaction conversion is thermodynamically limited. An increase in temperature increases the reaction rate but, at the same time, decreases the equilibrium conversion. An increase in pressure increases the equilibrium conversion. The catalyst accelerates both, the rate of formation and the rate of decomposition and thus, the composition of the exit stream is close to that predicted by thermodynamics.

In the electrocatalytic synthesis, the effect of temperature is similar to that in the conventional catalytic process. The effect of pressure, however, is quite different. When the reaction is carried out in the cell-reactor depicted in Figure 1, the half-cell reaction that takes place on the WE (catalyst) is reaction (3). In other words, reaction (1), in which four volumes of reactants produce two volumes of product, is replaced by reaction (3), in which one volume of reactant produces two volumes of product. Hence, the effect of pressure is essentially reversed (Marnellos et al., 1996; Panagos et al., 1996).

In addition to the above, several additional factors affect the electrocatalytic reaction rate. The effects of these additional factors have been presented in the review by Amar et al. (2011a) and are briefly summarized here.

\section{EFFECT OF CELL POTENTIAL}

There is a minimum voltage difference, below which it is not possible to produce $\mathrm{NH}_{3}$ electrochemically. This threshold value can be calculated from thermodynamics. If $\Delta G_{\mathrm{R}^{\circ}}$ is the Gibbs free energy change for reaction (1), the corresponding standard emf of the cell reaction, $E^{\mathrm{o}}$, will be given from the equation (Bard and 
Faulkner, 1980):

$$
\Delta G_{\mathrm{R}^{\circ}}=-n F E^{\mathrm{o}}
$$

where $F$ is Faraday's constant and $n$ is the number of electrons passed per mole of $\mathrm{N}_{2}$ reacted. According to Eqs 2 and 3, $n=6$. Using Eq. 12, the values of $E^{\mathrm{o}}$ at 25 and $500^{\circ} \mathrm{C}$ are found to be 0.057 and $-0.123 \mathrm{~V}$, respectively. If the hydrogen source is $\mathrm{H}_{2} \mathrm{O}$ rather than $\mathrm{H}_{2}$ (reaction 7 ), the standard corresponding emf values are -1.13 and $-1.21 \mathrm{~V}$ at 25 and $500^{\circ} \mathrm{C}$, respectively. The effect of imposed potential on the rate of formation of $\mathrm{NH}_{3}$ was studied in only a few of the works listed in Table 1 (Amar et al., 2011a). According to Li et al. (2005b), who studied the reaction at $480^{\circ} \mathrm{C}$, the reaction rate increased upon increasing the potential from 0 to $0.6 \mathrm{~V}$ while at higher voltages, upon increasing the potential, the rate gradually leveled off (Li et al., 2005b; Amar et al., 2011a).

\section{EFFECT OF CURRENT}

The effect of applied current is similar to that of the potential. The reaction rate increases with the imposed current up to a certain value above which, the rate is essentially current independent (Guo et al., 2009; Amar et al., 2011a). This is because at higher currents the coverage of $\mathrm{H}^{+}$on the catalyst surface, or the three phase boundary, is much higher and thus protons combine with each other rather than with $\mathrm{N}_{\mathrm{ads}}$, forming $\mathrm{H}_{2}$ rather than $\mathrm{NH}_{3}$. Another reason could be that the competition between $\mathrm{H}$ and $\mathrm{N}$ species on the catalyst surface. In fact, the effects of current and voltage are coupled because, in a cell operating at certain temperature and reactant composition, it is not possible to change the current without affecting the cell potential and vice versa.

\section{EFFECT OF ELECTROLYTE}

As opposed to the catalytic process, in the electrocatalytic synthesis, one of the reactants is supplied electrochemically. Thus, the electrolyte properties, and in particular the protonic conductivity, are crucial because they determine the maximum rate of proton supply. The conductivity of a solid electrolyte increases exponentially with temperature and is inversely proportional to the thickness of the electrolyte (Gellings and Bouwmeester, 1997). By reducing the electrolyte thickness, the same proton flux is attainable at a lower temperature. Reducing the thickness, on the other hand, may reduce mechanical stability.

\section{EFFECT OF WORKING ELECTRODE (CATALYST)}

The WE must meet the requirements of both catalytic activity and electric conductivity. As electrode material, it should exhibit acceptably high electronic conductivity. The conductivity of the industrial $\mathrm{NH}_{3}$ synthesis catalysts is very poor and this is a problem to be solved before application in an SSAS system.

Table 1 shows that SSAS has been studied in a large number of solid electrolyte cells. More than $30 \mathrm{H}^{+}$conducting materials have been tested including perovskite oxides, pyrochlores, and fluorites (Amar et al., 2011a; Giddey et al., 2013). Strictly speaking, polymer electrolytes cannot be considered as solid state materials (Amar et al., 2011a). Polymer electrolytes such as Nafion and SPSF, however, have been included in Table $\mathbf{1}$ for comparison purposes. Table 1 also shows that at least 15 different materials were used as WEs. The first catalyst tested was palladium (Marnellos and Stoukides, 1998) because it was assumed that the cathode should also act as an effective hydrogen "trap," i.e., the electrochemically supplied hydrogen would not desorb to form gaseous $\mathrm{H}_{2}$ but react on the surface to form $\mathrm{NH}_{3}$ (Marnellos et al., 1996; Panagos et al., 1996). Following Pd, several catalysts have been tested in the last 15 years, including $\mathrm{Ru}, \mathrm{Fe}, \mathrm{Pt}, \mathrm{Ag}-\mathrm{Pd}$, as well as conductive oxides and composite materials such as SSN, BSCF, SSCO, etc. The Ag$\mathrm{Pd}$ cathode was used in almost half of the SSAS studies, although most of the low temperature work used an Sm based mixed oxide (Table 1).

Table 3 contains information on both, rate of $\mathrm{NH}_{3}$ production and electrolyte conductivity for studies presented in Tables $\mathbf{1}$ and 2 . The first and second columns show the reference and operating temperature of each work. The third and fourth columns contain the type of WE and electrolyte used in each study. The fifth column shows the electrical conductivity of the electrolyte (in S/cm), calculated at the operating temperature. The sixth column shows the catalytic activity of the WE. The reaction rate, $r_{\mathrm{NH}_{3}}$, is expressed in moles of $\mathrm{NH}_{3}$ produced per second and per square centimeter of electrode area. The last column shows the percentage Faradaic Efficiency, FE (\%), which is defined as the percentage of protons that is converted to ammonia. To calculate FE (\%), one has to divide $r_{\mathrm{NH}_{3}}$ by the maximum rate of $\mathrm{NH}_{3}$ formation, $r_{\text {max }}$, for a given proton flux. The latter can be calculated from the equation:

$$
r_{\max }=\frac{2}{3} \frac{1 \cdot t_{\mathrm{H}^{+}}}{2 \cdot F \cdot A}=\frac{1 \cdot t_{\mathrm{H}^{+}}}{3 \cdot F \cdot A},
$$

where $A$ is the surface area of the WE (in $\mathrm{cm}^{2}$ ), $I$ is the current and $t_{\mathrm{H}+}$ is the proton $\left(\mathrm{H}^{+}\right)$transport number, i.e., the fraction of the total charge that is carried by protons. Using Eq. 13, the FE (\%) will be:

$$
\mathrm{FE}(\%)=\frac{3 \cdot F \cdot A \cdot r_{\mathrm{NH}_{3}}}{1 \cdot t_{H^{+}}} \cdot 100 .
$$

Values for $t_{\mathrm{H}}+$ were reported in only a few of the SSAS studies of Table 1. Where not reported, it was assumed that $t_{\mathrm{H}+}=1$.

There are certain points that are worth mentioning. The first point refers to the catalytic activity of $\mathrm{Pd}, \mathrm{Ag}-\mathrm{Pd}$, and $\mathrm{Pt}$. The industrial ammonia synthesis catalysts are $\mathrm{Fe}$ and $\mathrm{Ru}$ based materials. Some bimetallic systems have also been studied, with a combination of Fe and Co exhibiting the best results (Liu, 2013). Table 3, however, shows that at temperatures between 450 and $600^{\circ} \mathrm{C}$, the $\mathrm{Pd}-\mathrm{Ag}$ electrode exhibits high electrocatalytic activity as well as substantially high Faradaic Efficiency (50-80\%). One possible explanation could be that the mechanism of the electrocatalytic synthesis is different from that of the catalytic. In the Haber-Bosch synthesis, it is well established that nitrogen and hydrogen do not react until the strong triple bond of the $\mathrm{N}_{2}$ molecule has been broken (dissociative mechanism). In the low temperature metalloenzyme synthesis, however, nitrogen molecules are hydrogenated without prior rupture of the $\mathrm{N}-\mathrm{N}$ bond (associated mechanism) (Rod et al., 2000; Skúlason et al., 2012).

The experimental information obtained so far on SSAS is not sufficient to favor either the associative or the dissociative mechanism. Skulason et al. however, published recently a 
Table 3 | Reaction rates and Faradaic efficiencies.

\begin{tabular}{|c|c|c|c|c|c|c|}
\hline Reference & $T\left({ }^{\circ} \mathrm{C}\right)$ & $\begin{array}{l}\text { Working } \\
\text { electrode }\end{array}$ & Electrolyte & $\begin{array}{l}\text { Conductivity } \\
\text { (S/cm) }\end{array}$ & $\begin{array}{l}r_{\mathrm{NH}_{3}} \\
\left(\mathrm{~mol} / \mathrm{s} . \mathrm{cm}^{2}\right)\end{array}$ & FE (\%) \\
\hline Wang et al. (2005b) & 650 & $\mathrm{Ag}-\mathrm{Pd}$ & YDCPK & $2.3 \times 10^{-2}$ & $9.5 \times 10^{-9}$ & $\approx 40$ \\
\hline $\begin{array}{l}\text { Marnellos and Stoukides } \\
\text { (1998), Marnellos et al. (2000) }\end{array}$ & 570 & $\mathrm{Pd}$ & SCY & $1.9 \times 10^{-3}$ & $4.5 \times 10^{-9}$ & 78 \\
\hline Zhang et al. (2007) & 550 & $\mathrm{Ag}-\mathrm{Pd}$ & LSGM & $3.9 \times 10^{-3}$ & $2.37 \times 10^{-9}$ & $\approx 70$ \\
\hline Wang et al. (2010a) & 530 & $\mathrm{Ag}-\mathrm{Pd}$ & $\mathrm{BCD}$ & $0.93 \times 10^{-2}$ & $3.5 \times 10^{-9}$ & $\approx 80$ \\
\hline Wang et al. (2010b) & 530 & BSCF & $\mathrm{BCY}$ & $7 \times 10^{-3}$ & $4.1 \times 10^{-9}$ & 60 \\
\hline Chen and Ma (2008) & 520 & $\mathrm{Ag}-\mathrm{Pd}$ & LBGM & $0.82 \times 10^{-2}$ & $1.89 \times 10^{-9}$ & $\approx 60$ \\
\hline Guo et al. (2009) & 500 & $\mathrm{Ag}-\mathrm{Pd}$ & $\mathrm{BCY}$ & $5.4 \times 10^{-3}$ & $2.1 \times 10^{-9}$ & $\approx 60$ \\
\hline Wang et al. (2011) & 500 & $\mathrm{Ag}-\mathrm{Pd}$ & BCZS & $4 \times 10^{-3}$ & $2.67 \times 10^{-9}$ & $\approx 80$ \\
\hline Liu et al. (2010) & 480 & $\mathrm{Ag}-\mathrm{Pd}$ & $\mathrm{BCC}$ & $2.34 \times 10^{-4}$ & $2.69 \times 10^{-9}$ & $\approx 50$ \\
\hline Amar et al. (2011c) & 450 & LSFCu-SDC & SDC-carbonate & $3.3 \times 10^{-3}$ & $5.39 \times 10^{-9}$ & $\approx 3.5$ \\
\hline Amar et al. (2011b) & 400 & CFO-Ag & Carbonate-LiAlO 2 & $4 \times 10^{-5}$ & $2.32 \times 10^{-10}$ & $\approx 2.5$ \\
\hline Kordali et al. (2000) & 90 & $\mathrm{Ru} / \mathrm{C}$ & Nafion & $4.5 \times 10^{-2}$ & $2.12 \times 10^{-11}$ & $<1$ \\
\hline Liu and Xu (2010) & 80 & SSN & Nafion & $4.5 \times 10^{-2}$ & $1.05 \times 10^{-8}$ & $<1$ \\
\hline Liu and Xu (2010) & 80 & SSN & SPSF & $5 \times 10^{-2}$ & $1.03 \times 10^{-8}$ & $<1$ \\
\hline Xu et al. (2009) & 80 & SFCN & SPSF & $5 \times 10^{-2}$ & $1.13 \times 10^{-8}$ & 90.4 \\
\hline Zhang et al. (2010) & 80 & SBCN & Nafion & $4.5 \times 10^{-2}$ & $8.7 \times 10^{-9}$ & $<1$ \\
\hline Lan et al. (2013) & 25 & $\mathrm{Pt}$ & mixed $\mathrm{NH}_{4}+/ \mathrm{H}^{+}$Nafion & $5 \times 10^{-2}$ & $3.1 \times 10^{-9}\left(\mathrm{~N}_{2}+\mathrm{H}_{2}\right)$ & 2.2 \\
\hline Lan et al. (2013) & 25 & $\mathrm{Pt}$ & mixed $\mathrm{NH}_{4}+/ \mathrm{H}^{+}$Nafion & $5 \times 10^{-2}$ & $1.14 \times 10^{-9}\left(\right.$ Air $\left.+\mathrm{H}_{2} \mathrm{O}\right)$ & $<1$ \\
\hline Lan and Tao (2013) & 80 & $\mathrm{Pt}-\mathrm{C}$ & $\begin{array}{l}\mathrm{H}^{+} / \mathrm{Li}^{+} / \mathrm{NH}_{4}+\text { mixed } \\
\text { conducting membrane }\end{array}$ & $5.1 \times 10^{-3}$ & $9.37 \times 10^{-10}$ & $<1$ \\
\hline
\end{tabular}

theoretical evaluation of metal electro-catalysts for electrochemical ammonia synthesis. The most active surfaces were $\mathrm{Fe}, \mathrm{Ru}$, Mo, and $\mathrm{Rh}$, although the formation of gaseous $\mathrm{H}_{2}$ reduced the Faradaic Efficiency. The catalytic activity of platinum and palladium were among the lowest for this reaction. It was also found that early transition metals such as $\mathrm{Sc}, \mathrm{Y}, \mathrm{Ti}$, and $\mathrm{Zr}$ bind $\mathrm{N}$ adatoms stronger than $\mathrm{H}$-adatoms and therefore, upon imposing a negative voltage, these metals can effectively catalyze ammonia synthesis (Skúlason et al., 2012). The catalytic activity of early transition metals may explain the high reaction rates and Faradaic Efficiencies reported for Pd and Ag-Pd. Most of the solid electrolytes used in the works listed in Table 1 (e.g., SZY, LSGM, SCY, BCY) contain transition metals such as $\mathrm{Y}, \mathrm{Zr}, \mathrm{Ce}, \mathrm{Yb}$, etc. Moreover, under reaction conditions (closed circuit, $450-600^{\circ} \mathrm{C}$ ), several changes may occur in the structure of these materials. For example, in the $\mathrm{SrCe}_{0.95} \mathrm{Yb}_{0 \cdot 05} \mathrm{O}_{3-a}$ (SCY) electrolyte used by Marnellos and Stoukides (1998), EDS analysis showed that $\mathrm{Sr}$ and $\mathrm{Yb}$ had migrated from the bulk of the electrolyte to the $\mathrm{Pd}-\mathrm{SCY}$ interphase. Thus, the observed activity of Pd and Ag-Pd could be attributed to the presence of early transition metals at the electrode-electrolyte interphase.

The second point refers to the dependence of $r_{\mathrm{NH}_{3}}$ and FE on temperature. The highest rates of $\mathrm{NH}_{3}$ formation were obtained at low temperatures $\left(25-90^{\circ} \mathrm{C}\right)$, while, with the exception of the study by $\mathrm{Xu}$ et al. (2009), at temperatures between 500 and $650^{\circ} \mathrm{C}$, the FE values are at least one order of magnitude higher than those attained with Nafion and SPSF, at low temperatures $\left(25-90^{\circ} \mathrm{C}\right)$. The conductivity values (fifth column of Table 3 ) can give an explanation for this. The conductivity of Nafion and SPSF is much higher than that of the ceramic high temperature conductors. On the other hand, the catalytic reaction rate increases with temperature. Thus, at low temperatures, only a small fraction of the electrochemically supplied protons react to produce ammonia. At high temperatures, the catalytic activity increases and thus, FE increases as well. The rates of $\mathrm{H}^{+}$transport through the ceramic electrolytes, however, remain much lower than those in Nafion and SPSF.

\section{ECONOMIC CONSIDERATIONS AND FUTURE OUTLOOK}

Ammonia is one of the top-ranking chemicals in terms of volume, primarily due to its use in the fertilizer industry. Its global annual production is well in excess of 100 million tons with a tendency to increase further (Amar et al., 2011a). It is also, a significant component of the world energy budget, as its production accounts for more than $1 \%$ of man-made power consumption. Furthermore, as the combustion of ammonia as opposed to carbon-containing fuels, releases only $\mathrm{H}_{2} \mathrm{O}$ and $\mathrm{N}_{2}$ to the environment, it has been proposed as a practical alternative to fossil fuels for internal combustion engines and even fuel cells, either directly or after decomposition (Schüth et al., 2012). Also, since ammonia is an excellent carbon-free hydrogen storage medium, SSAS can be combined with plants, which produce energy from renewable sources (solar or wind energy).

The interest in all methods of ammonia synthesis, including SSAS, is thus expected to continue to increase. There are certain advantages of SSAS vs. the conventional Haber-Bosch process. A large percentage of the cost in the industrial production of ammonia lies in the preparation and purification of the reactant gases. Water vapor and carbon monoxide can cause a reversible poisoning if their concentrations are small, while trace amounts of 
oxygen and most sulfur compounds cause irreversible poisoning of the catalyst (Satterfield, 1980; Boudart, 1994; Topsoe et al., 1994). Therefore, extensive and costly pre-purification of the nitrogen $\left(\mathrm{O}_{2}\right.$ removal $)$ and hydrogen $\left(\mathrm{H}_{2} \mathrm{O}\right.$ and $\mathrm{CO}$ removal $)$ is necessary to minimize poisoning. In SSAS, with hydrogen source being either $\mathrm{H}_{2} \mathrm{O}$ or $\mathrm{H}_{2}$, only one of the reactants, $\mathrm{N}_{2}$, needs purification.

On the other hand, several technical and material requirements must be met in SSAS (Kokkofitis et al., 2007; Amar et al., 2011a; Garagounis et al., 2011). Firstly, the catalyst will also serve as the WE and therefore must exhibit, not only high catalytic activity toward ammonia synthesis, but also adequately high electronic conductivity. Precious metals based on Pd and Ru have been found to satisfy these demands. If these metals are to be used, then the quantity of catalyst required per unit cell should be kept to a minimum (Giddey et al., 2013). Secondly, in addition to mechanical strength and chemical stability, the electrolyte material should exhibit high protonic conductivity at the temperature of operation. As seen in Table 3, there are no materials with high protonic conductivity at temperatures between 100 and $500^{\circ} \mathrm{C}$. This is unfortunate because at low temperatures, although the protonic conductivity of certain materials is substantially high, low catalytic reaction rates are obtained, while at high temperatures the Faradaic Efficiency can be acceptably high, but the reaction rate is limited by the proton conductivity of the electrolyte.

In the past 15 years, many researchers worldwide have contributed to the improvement of the SSAS process. New proton conductors have been prepared and tested and catalytically effective WEs have been employed. Notably, Lan et al. (2013) recently synthesized ammonia from air and water at ambient temperature using Pt electrodes. Robinson et al. (2012, 2013) fabricated high temperature $\left(650-850^{\circ} \mathrm{C}\right)$, thin, tubular ceramic proton conductors through which they passed as many as $5.5 \times 10^{-6} \mathrm{~mol} \mathrm{H}_{2} / \mathrm{scm}^{2}$, while $\mathrm{Xu}$ et al. (2009) reported the highest ammonia production rate so far, i.e., $1.13 \times 10^{-8} \mathrm{~mol} \mathrm{~cm}^{-2} \mathrm{~s}^{-1}$, when employing a Nafion membrane and an $\mathrm{SmFe}_{0.7} \mathrm{Cu}_{0.3-}{ }_{x} \mathrm{Ni}_{x} \mathrm{O}_{3}$ cathode. Along the lines of electrolytes with high conductivity at intermediate-temperatures $\left(150-300^{\circ} \mathrm{C}\right)$ the recent work of Martsinkevich and Ponomareva (2012), who fabricated electrolyte materials exhibiting maximum proton conductivity at $200-220^{\circ} \mathrm{C}$, offers an alternative that is worth investigation.

If current densities similar to those achieved in fuel or electrolysis cells $\left(0.25-0.5 \mathrm{~A} \mathrm{~cm}^{-2}\right)$ were achievable simultaneously with an FE (\%) of approximately $50 \%$, then commercially viable production rates (in the range $4.3-8.7 \times 10^{-7} \mathrm{~mol} \mathrm{~cm}^{-2} \mathrm{~s}^{-1}$ ) could be attained (Giddey et al., 2013). The lack of information concerning long term stability of most materials and electrochemical cells in ammonia containing environments is partly due to the relatively early stage of development of this technology (Giddey et al., 2013). Such information, along with the actual cost of fabrication, would be necessary for a comprehensive economic assessment (life-cycle analysis) of an SSAS plant.

\section{ACKNOWLEDGMENTS}

We gratefully acknowledge financial support of this research by the European Union and the General Secretariat of Research and Technology of Greece (Program ARISTEIA, Project Number 1089).

\section{REFERENCES}

Amar, I. A., Lan, R., Petit, C. T. G., and Tao, S. (2011a). Solid-state electrochemical synthesis of ammonia: a review. J. Solid State Electrochem. 15, 1845-1860. doi:10.1007/s10008-011-1376-x

Amar, I. A., Lan, R., Petit, C. T. G., Arrighi, V., and Tao, S. (2011b). Electrochemical synthesis of ammonia based on a carbonate-oxide composite electrolyte. Solid State Ionics 182, 133-138. doi:10.1016/j.ssi.2010.11.009

Amar, I. A., Petit, C. T. G., Zhang, L., Lan, R., Skabara, P. J., and Tao, S. (2011c). Electrochemical synthesis of ammonia based on doped-ceria-carbonate composite electrolyte and perovskite cathode. Solid State Ionics 201, 94-100. doi:10.1016/j.ssi.2011.08.003

Bard, A. J., and Faulkner, L. R. (1980). Electrochemical Methods. New York: John Wiley \& Sons.

Boudart, M. (1994). Ammonia synthesis: the bellwether reaction in heterogeneous catalysis. Top. Catal. 1, 405-415. doi:10.1007/BF01492292

Chen, C., and Ma, G. (2008). Preparation, proton conduction, and application in ammonia synthesis at atmospheric pressure of $\mathrm{La}_{0.9} \mathrm{Ba}_{0.1} \mathrm{Ga}_{1-\mathrm{x}} \mathrm{Mg}_{\mathrm{x}} \mathrm{O}_{3-\alpha}$. J. Mater. Sci. 43, 5109-5114. doi:10.1007/s10853-008-2747-2

Chen, C., and Ma, G. (2009). Proton conduction in $\mathrm{BaCe}_{1-\mathrm{x}} \mathrm{Gd}_{\mathrm{x}} \mathrm{O}_{3-\alpha}$ at intermediate temperature and its application to synthesis of ammonia at atmospheric pressure. J. Alloys Comp. 485, 69-72. doi:10.1016/j.jallcom.2009.05.108

Chen, C., Wang, W., and Ma, G. (2009). Proton conduction in $\mathrm{La}_{0.9} \mathrm{M}_{0.1} \mathrm{cGa}_{0.8} \mathrm{Mg}_{0.2} \mathrm{O}_{3-\alpha}$ at intermediate temperature and its application to synthesis of ammonia at atmospheric pressure. Acta Chim. Sin. 67, 623-628.

Denvir, A. J., Murphy, O. J., Cisar, A., Robertson, P., and Uselton, K. (2004). Electrochemical synthesis of ammonia. US Patent 6, 950.

Garagounis, I., Kyriakou, V., Anagnostou, C., Bourganis, V., Papachristou, I., and Stoukides, M. (2011). Solid electrolytes: applications in heterogeneous catalysis and chemical cogeneration. Ind. Eng. Chem. Res. 50, 431-472. doi:10.1021/ ie1001058

Garagounis, I., Kyriakou, V., and Stoukides, M. (2013). Electrochemical promotion of catalytic reactions: thermodynamic analysis and calculation of the limits in Faradaic efficiency. Solid State Ionics 231, 58-62. doi:10.1016/j.ssi.2012. 10.019

Gellings, P. J., and Bouwmeester, H. J. M. (1997). The CRC Handbook of Solid State Electrochemistry. New York: CRC Press Inc.

Giddey, S., Badwal, S. P. S., and Kulkarni, A. (2013). Review of electrochemical ammonia production technologies and materials. Int. J. Hydrogen Energy 38, 14576-14594. doi:10.1016/j.ijhydene.2013.09.054

Guo, Y., Liu, B., Yang, Q., Chen, C., Wang, W., and Ma, G. (2009). Preparation via microemulsion method and proton conduction at intermediate-temperature of $\mathrm{BaCe}_{1-\mathrm{x}} \mathrm{Y}_{\mathrm{x}} \mathrm{O}_{3-\delta}$ by the citrate method and its application in the synthesis of ammonia at atmospheric pressure. Electrochem. Commun. 11, 153-156. doi:10.1016/j.elecom.2008.10.038

Iwahara, H., Esaka, T., Uchida, H., and Tanaka, N. (1981). Proton conduction in sintered oxides and its application to steam electrolysis for hydrogen production. Solid State Ionics 4, 359-363. doi:10.1016/0167-2738(81)90113-2

Kokkofitis, C., Ouzounidou, M., Skodra, A., and Stoukides, M. (2007). High temperature proton conductors: applications in catalytic processes. Solid State Ionics 178, 507-513. doi:10.1016/j.ssi.2006.11.010

Kőleli, F., and Rőpke, T. (2006). Electrochemical hydrogenation of dinitrogen to ammonia on a polyaniline electrode. Appl. Catal. B Environ. 62, 306-310. doi:10.1016/j.apcatb.2005.08.006

Kordali, V., Kyriakou, G., and Lambrou, C. (2000). Electrochemical synthesis of ammonia at atmospheric pressure and low temperature in a solid polymer electrolyte cell. Chem. Commun. 1673-1674. doi:10.1039/b004885m

Lan, R., Irvine, J. T. S., and Tao, S. (2013). Synthesis of ammonia directly from air and water at ambient temperature and pressure. Sci. Rep. 3, 1145. doi:10.1038/srep01145

Lan, R., and Tao, S. (2013). Electrochemical synthesis of ammonia directly from air and water using a $\mathrm{Li}^{+} / \mathrm{H}^{+} / \mathrm{NH}_{4}{ }^{+}$mixed conducting electrolyte. RSC Adv. 3, 18016. doi:10.1039/c3ra43432j

Li, S. Z., Liu, R. Q., Xie, Y. H., Feng, S., and Wang, J. D. (2005a). A novel method for preparation of doped $\mathrm{Ba}_{3}\left(\mathrm{Ca}_{1.18} \mathrm{Nb}_{1.82}\right) \mathrm{O}_{9-\delta}$ : application to ammonia synthesis at atmospheric pressure. Solid State Ionics 176, 1063-1066. doi:10.1016/j. ssi.2005.01.009

Li, S. Z., Liu, R. Q., Wang, J. D., Xie, Y. H., and Yue, F. J. (2005b). Preparation $\mathrm{BaCe}_{0.8} \mathrm{Gd}_{0.2} \mathrm{O}_{3-\delta}$ by the citrate method and its application in the synthesis 
of ammonia at atmospheric pressure. Solid State Electrochem. 9, 201-204. doi:10.1007/s10008-004-0582-1

Li, Z., Liu, R. Q., Wang, J. D., Xu, Z., Xie, Y. H., and Wang, B. H. (2007). Preparation of double-doped $\mathrm{BaCeO} 3$ and its application in the synthesis of ammonia at atmospheric pressure. Sci. Technol. Adv. Mater. 8, 566-570. doi:10.1016/j.stam.2007.08.009

Liu, H. (2013). Ammonia Synthesis Catalysts. Innovation and Practice. Beijing: World Scientific.

Liu, J., Li, Y., Wang, W., Wang, H., Zhang, F., and Ma, G. (2010). Proton conduction at intermediate temperature and its application in ammonia synthesis at atmospheric pressure of $\mathrm{BaCe}_{1-\mathrm{x}} \mathrm{Ca}_{\mathrm{x}} \mathrm{O}_{3-\alpha}$. J. Mater. Sci. 45, 5860-5864. doi:10.1007/s10853-010-4662-6

Liu, R. Q., Xie, Y. H., Li, S. Z., Wang, J. D., and Sun, Y. G. (2005). Application of proton conductors $\left(\mathrm{Ce}_{0.8} \mathrm{La}_{0.2}\right)_{1-\mathrm{x}} \mathrm{Ca}_{\mathrm{X}} \mathrm{O}_{2-\delta}$ in synthesis of ammonia. Acta Phys. Chim. Sin. 21, 967-970.

Liu, R. Q., Xie, Y. H., Wang, J. D., Li, S. Z., and Wang, B. H. (2006). Synthesis of ammonia at atmospheric pressure with $\mathrm{Ce}_{0.8} \mathrm{M}_{0.2} \mathrm{O}_{2-\delta}(\mathrm{M} \mathrm{La}, \mathrm{Y}, \mathrm{Gd}, \mathrm{Sm})$ and their proton conduction at intermediate temperature. Solid State Ionics 177, 73-76. doi:10.1016/j.ssi.2005.07.018

Liu, R. Q., and Xu, G. C. (2010). Comparison of electrochemical synthesis of ammonia by using sulfonated polysulfone and nafion membrane with $\mathrm{Sm}_{1.5} \mathrm{Sr}_{0.5} \mathrm{NiO}_{4}$. Chin. J. Chem. 28, 139-142. doi:10.1002/cjoc.201090044

Marnellos, G., Athanasiou, C., and Stoukides, M. (1998). Evaluation and use of the $\mathrm{H}_{2} / \mathrm{Pd} / \mathrm{SrCe}_{0.95} \mathrm{Yb}_{0.05} \mathrm{O}_{3} / \mathrm{Pd} / \mathrm{N}_{2}$ electrochemical reactor for equilibrium-limited hydrogenation reactions. Ionics 4, 141-148. doi:10.1007/BF02375792

Marnellos, G., Athanasiou, C., Tsiakaras, P., and Stoukides, M. (1996). Modeling of solid $\mathrm{H}^{+}$conducting cells: thermodynamics and kinetics. Ionics 2, 412-419. doi:10.1007/BF02375820

Marnellos, G., Sanopoulou, O., Rizou, A., and Stoukides, M. (1997). The use of proton conducting solid electrolytes for improved performance of hydro- and dehydrogenation reactors. Solid State Ionics 97, 375-380. doi:10.1016/S01672738(97)00088-X

Marnellos, G., and Stoukides, M. (1998). Ammonia synthesis at atmospheric pressure. Science 282, 95-98. doi:10.1126/science.282.5386.98

Marnellos, G., Zisekas, S., and Stoukides, M. (2000). Synthesis of ammonia at atmospheric pressure with the use of solid state proton conductors. J. Catal. 193, 80-88. doi:10.1006/jcat.2000.2877

Martsinkevich, V. V., and Ponomareva, V. G. (2012). Double salts $\mathrm{Cs}_{1-\mathrm{x}} \mathrm{M}_{\mathrm{X}} \mathrm{H}_{2} \mathrm{PO}_{4}$ $(\mathrm{M}=\mathrm{Na}, \mathrm{K}, \mathrm{Rb})$ as proton conductors. Solid State Ionics 225, 236-240. doi:10.1016/j.ssi.2012.04.016

McFarlan, A., Pelletier, L., and Maffei, N. (2004). An intermediate-temperature ammonia fuel cell using Gd-doped barium cerate electrolyte. J. Electrochem. Soc. 151, A930-A932. doi:10.1149/1.1738133

Murakami, T., Nishikiori, T., Nohira, T., and Ito, Y. (2003). Electrolytic synthesis of ammonia in molten salts under atmospheric pressure. J. Amer. Chem. Soc. 125, 334-335. doi:10.1021/ja028891t

Murakami, T., Nohira, T., Goto, T., Ogata, Y. H., and Ito, Y. (2005). Electrocatalytic ammonia synthesis from water and nitrogen gas in molten salt under atmospheric pressure. Electrochim. Acta 50, 5423-5426. doi:10.1016/j.electacta.2005. 03.023

Murphy, O. J., Denvir, A. J., Teodorescu, S. G., and Uselton, K. B. (2008). Electrochemical synthesis of ammonia. US Patent 7, 544.

Ouzounidou, M., Skodra, A., Kokkofitis, C., and Stoukides, M. (2007). Catalytic and electrocatalytic synthesis of $\mathrm{NH}_{3}$ in a $\mathrm{H}^{+}$conducting cell by using an industrial Fe catalyst. Solid State Ionics 178, 153-159. doi:10.1016/j.ssi.2006.11.019

Panagos, E., Voudouris, I., and Stoukides, M. (1996). Modelling of equilibrium limited hydrogenation reaction carried out in $\mathrm{H}^{+}$conducting solid oxide membrane reactors. Chem. Eng. Sci. 51, 3175-3180. doi:10.1016/0009-2509(96)00216-3

Pelletier, L., McFarlan, A., and Maffei, N. (2005). Ammonia fuel cell using doped barium cerate proton conducting solid electrolytes. J. Power Sources 145, 262-265. doi:10.1016/j.jpowsour.2005.02.040

Pitselis, G. E., Petrolekas, P. D., and Vayenas, C. G. (1997). Electrochemical promotion of ammonia decomposition over Fe catalyst films interfaced with $\mathrm{K}^{+} \& \mathrm{H}^{+}$ conductors. Ionics 3, 110-119.

Robinson, S., Manerbino, A., and Coors, W. G. (2013). Galvanic hydrogen pumping in the protonic ceramic perovskite $\mathrm{BaCe}_{0.2} \mathrm{Zr}_{0.7} \mathrm{Y}_{0.1} \mathrm{O}_{3-\delta}$. J. Membr. Sci. 446, 99-105. doi:10.1016/j.memsci.2013.06.026
Robinson, S., Manerbino, A., Coors, W. G., and Sullivan, N. P. (2012). Fuel cells. From fundamentals to systems. Paper Presented at the 10th European Fuel Cell Forum, Lake Lucerne.

Rod, T. H., Logadottir, A., and Nørskov, J. K. (2000). Ammonia synthesis at low temperatures. J. Chem. Phys. 112, 5343-5347. doi:10.1063/1.481103

Satterfield, C. N. (1980). Heterogeneous Catalysis in Practice. New York: McGrawHill.

Schrock, R. (2006). Nitrogen fix. MIT Technol. Rev. Mag. 2006, 14.

Schüth, F., Palkovits, R., Schlögl, R., and Su, D. S. (2012). Ammonia as a possible element in an energy infrastructure: catalysts for ammonia decomposition. Energy Environ. Sci. 5, 6278-6289. doi:10.1039/c2ee02865d

Serizawa, N., Miyashiro, H., Takei, K., Ikezumi, T., Nishikiori, T., and Ito, Y. (2012). Dissolution behavior of ammonia electrosynthesized in molten $\mathrm{LiCl}-\mathrm{KCl}-\mathrm{CsCl}$ system. J. Electrochem. Soc. 159, E87-E91. doi:10.1149/2.099204jes

Skodra, A., Ouzounidou, M., and Stoukides, M. (2006). $\mathrm{NH}_{3}$ decomposition in a single chamber proton-conducting cell. Solid State Ionics 177, 2217-2220. doi:10.1016/j.ssi.2006.03.051

Skodra, A., and Stoukides, M. (2009). Electrocatalytic synthesis of ammonia from steam and nitrogen at atmospheric pressure. Solid State Ionics 180, 1332-1336. doi:10.1016/j.ssi.2009.08.001

Skúlason, E., Bligaard, T., Gudmundsdóttir, S., Studt, F., Rossmeisl, J., AbildPedersen, F., et al. (2012). A theoretical evaluation of possible transition metal electro-catalysts for $\mathrm{N}_{2}$ reduction. Phys. Chem. Chem. Phys. 14, 1235-1245. doi:10.1039/clcp22271f

Studt, F., and Tuczec, F. (2005). Energetics and mechanism of a room-temperature catalytic process for ammonia synthesis (Schrock Cycle): comparison with biological nitrogen fixation. Angew. Chem. Int. Ed. 44, 5639-5642. doi:10.1002/anie. 200501485

Topsoe, H., Boudart, M., and Norskov, J. K. (1994). Frontiers in catalysis: ammonia synthesis and beyond. Top. Catal. 1, 185-414.

Tsuneto, A., Kudo, A., and Sakata, T. (1994). Lithium-mediated electrochemical reduction of high pressure $\mathrm{N}_{2}$ to $\mathrm{NH}_{3}$. J. Electroanal. Chem. 367, 183-188. doi:10.1016/0022-0728(93)03025-K

Vayenas, C. G. (2011). Bridging electrochemistry and heterogeneous catalysis. J. Solid State Electrochem. 15, 1425-1435. doi:10.1007/s10008-011-1336-5

Vayenas, C. G., Bebelis, S., Pliangos, C., Brosda, S., and Tsiplakides, D. (2001). Electrochemical Activation of Catalysis: Promotion, Electrochemical Promotion and Metal-Support Interactions. New York: Kluwer/Plenum Publishers.

Vayenas, C. G., and Koutsodontis, C. G. (2008). Non-Faradaic electrochemical activation of catalysis. J. Chem. Phys. 128, 182506-182511. doi:10.1063/1. 2824944

Wang, B. H., Wang, J. D., Li, Z. J., and Xie, Y. H. (2007). Synthesis of ammonia from natural gas at atmospheric pressure with doped Ceria- $\mathrm{Ca}_{3}\left(\mathrm{PO}_{4}\right)_{2}$ $\mathrm{K}_{3} \mathrm{PO}_{4}$ composite electrolyte and its proton conductivity at intermediate temperature. J. Solid State Electrochem. 11, 27-31. doi:10.1007/s10008-0050042-6

Wang, J., and Liu, R. Q. (2008). Property research of SDC and SSC in ammonia synthesis at atmospheric pressure and low temperature. Acta Chim. Sin. 66, 717-721.

Wang, J. D., Xie, Y. H., Zhang, Z. F., Liu, R. Q., and Li, Z. H. (2005a). Protonic conduction in $\mathrm{Ca}^{2+}$-doped $\mathrm{La}_{2} \mathrm{M}_{2} \mathrm{O}_{7}(\mathrm{M}=\mathrm{Ce}, \mathrm{Zr})$ with its application to ammonia synthesis electrochemically. Mater. Res. Bull. 40, 1294-1302. doi:10.1016/j.materresbull.2005.04.008

Wang, B. H., Liu, R. Q., Wang, J. D., Li, Z. H., and Xie, Y. H. (2005b). Doped ceria $\mathrm{Ca}_{3}\left(\mathrm{PO}_{4}\right)_{2}-\mathrm{K}_{3} \mathrm{PO}_{4}$ composite electrolyte: proton conductivity at intermediate temperature and application in atmospheric pressure ammonia synthesis. Chin. J. Inorg. Chem. 21, 1551-1555.

Wang, W. B., Liu, J. W., Li, Y. D., Wang, H. T., Zhang, F., and Ma, G. L. (2010a). Microstructures and proton conduction behaviors of Dy-doped $\mathrm{BaCeO}_{3}$ ceramics at intermediate temperature. Solid State Ionics 181, 667-671. doi:10.1016/j. ssi.2010.04.008

Wang, W. B., Cao, X. B., Gao, W. J., Zhang, F., Wang, H. T., and Ma, G. L. (2010b). Ammonia synthesis at atmospheric pressure using a reactor with thin solid electrolyte $\mathrm{BaCe}_{0.85} \mathrm{Y}_{0.15} \mathrm{O}_{3}$ membrane. J. Membr. Sci. 360, 397-403. doi:10.1016/j.memsci.2010.05.038

Wang, X., Yin, J., Xu, J., Wang, H., and Ma, G. (2011). Chemical stability, ionic conductivity of $\mathrm{BaCe}_{0.9-\mathrm{x}} \mathrm{Zr}_{\mathrm{x}} \mathrm{Sm}_{0.10} \mathrm{O}_{3-\alpha}$ and its application to ammonia synthesis 
at atmospheric pressure. Chin. J. Chem. 29, 1114-1118. doi:10.1002/cjoc. 201190209

Xie, Y. H., Wang, J. D., Liu, R. Q., and Su, X. T. (2004). Preparation of $\mathrm{La}_{1.9} \mathrm{Ca}_{0.1} \mathrm{Zr}_{2} \mathrm{O}_{6.95}$ with pyrochlore structure and its application in synthesis of ammonia at atmospheric pressure. Solid State Ionics 168, 117-121. doi:10.1016/j.ssi.2004.01.025

Xu, G. C., Liu, R. Q., and Wang, J. (2009). Electrochemical synthesis of ammonia using a cell with a Nafion membrane and $\mathrm{SmFe}_{0.7} \mathrm{Cu}_{0.3-\mathrm{x}} \mathrm{Ni}_{\mathrm{x}} \mathrm{O}_{3}(\mathrm{x}=0-0.3)$ cathode at atmospheric pressure and lower temperature. Sci. China B Chem. 52, 1171-1175. doi:10.1007/s11426-009-0135-7

Yandulov, D. V., and Schrock, R. (2003). Catalytic reduction of dinitrogen to ammonia at a single molybdenum center. Science 301, 76-78. doi:10.1126/science. 1085326

Yokari, C. G., Pitselis, G. E., Polydoros, D. G., Katsaounis, A. D., and Vayenas, C. G. (2000). High-pressure electrochemical promotion of ammonia synthesis over an industrial iron catalyst. J. Phys. Chem. A 104, 10600-10606. doi:10.1021/jp002236v

Zhang, F., Yang, Q., Pan, B., Xu, R., Wang, H., and Ma, G. (2007). Proton conduction in $\mathrm{La}_{0.9} \mathrm{Sr}_{0.1} \mathrm{Ga}_{0.8} \mathrm{Mg}_{0.2} \mathrm{O}_{3-\alpha}$ ceramic prepared via microemulsion method and its application in ammonia synthesis at atmospheric pressure. Mater. Lett. 61, 4144-4148. doi:10.1016/j.matlet.2007.01.060

Zhang, M., Xu, M., and Ma, G. (2011). Proton conduction in $\mathrm{Ba}_{\mathrm{x}} \mathrm{Ce}_{0.8} \mathrm{Y}_{0.2} \mathrm{O}_{3-\mathrm{a}}+$ $0.04 \mathrm{ZnO}$ at intermediate temperatures and its application in ammonia synthesis at atmospheric pressure. J. Mater. Sci. 46, 4690-4694. doi:10.1007/s10853-0115376-0
Zhang, Z., Zhong, Z., and Liu, R. (2010). Cathode catalysis performance of $\mathrm{SmBaCuMO}_{5-\delta}(\mathrm{M}=\mathrm{Fe}, \mathrm{Co}, \mathrm{Ni})$ in ammonia synthesis. J. Rare Earths 28, 556-559. doi:10.1016/S1002-0721(09)60153-8

Zisekas, S., Karagiannakis, G., Kokkofitis, C., and Stoukides, M. (2008). $\mathrm{NH}_{3}$ decomposition in a proton conducting solid electrolyte cell. J. Appl. Electrochem. 38, 1143-1150. doi:10.1007/s10800-008-9551-1

Conflict of Interest Statement: The authors declare that the research was conducted in the absence of any commercial or financial relationships that could be construed as a potential conflict of interest.

Received: 25 November 2013; paper pending published: 19 December 2013; accepted: 04 January 2014; published online: 17 January 2014.

Citation: Garagounis I, Kyriakou V, Skodra A, Vasileiou E and Stoukides M (2014) Electrochemical synthesis of ammonia in solid electrolyte cells. Front. Energy Res. 2:1. doi: 10.3389/fenrg.2014.00001

This article was submitted to Fuel Cells, a section of the journal Frontiers in Energy Research.

Copyright (C) 2014 Garagounis, Kyriakou, Skodra, Vasileiou and Stoukides. This is an open-access article distributed under the terms of the Creative Commons Attribution License (CC BY). The use, distribution or reproduction in other forums is permitted, provided the original author(s) or licensor are credited and that the original publication in this journal is cited, in accordance with accepted academic practice. No use, distribution or reproduction is permitted which does not comply with these terms. 